\title{
PEMODELAN SIMULASI PRODUKSI BAKSO DAN SISTEM DISTRIBUSI
}

\author{
Risky Agung Nurdian" ${ }^{1)}$, Rensa Prasidyajyandalu' ${ }^{2)}$, Moch. Bagoes Ali Masyhuri ${ }^{3)}$, Dwi \\ Rolliawati $^{4)}$ \\ ${ }^{1,2,3,4}$ Program Studi Sistem Informasi, Universitas Islam Negeri Sunan Ampel Surabaya \\ Email: riskiok19@gmail.com ${ }^{1)}$
}

\begin{abstract}
ABSTRAK
Persaingan yang ketat pada zaman sekarang menuntut produsen untuk meningkatkan efektivitas serta efisiensi sumber daya manusia dan sumber daya bahan produk. Produksi bakso X merupakan salah satu produksi industri kecil yang bergerak di bidang kuliner. Dalam proses produksi dan distribusinya produksi bakso X masih belum maksimal. Penelitian ini bertujuan untuk membuat pemodelan simulasi untuk memaksimalkan produksi dan distribusi pada produksi bakso X. Metode penelitian proses manufacturing bakso melewati 4 tahapan yaitu penggilingan, emulsifikasi, penyetakan, dan pengemasan. Dengan jumlah produksi perhari 1200 buah dan menghasilkan pendapatan maksimal sebesar Rp. 1.800.000 dengan laba bersih sebesar Rp. 1.025.000. Untuk menentukan rute dan lintasan distribusi terpendek menggunakan algoritma Dijkstra. Dari hasil perhitungan Dijkstra rute dan lintasan terpendek sejauh $14,1 \mathrm{Km}$.
\end{abstract}

\section{Kata kunci: Produksi, Distribusi, Pemodelan, Simulasi, Dijkstra}

\section{ABSTRACT}

Intense competition at the present time requires producers to increase the effectiveness and efficiency of human resources and product material supplies. Meatball X production is one of the small industrial productions engaged in the culinary field. In the production process and distribution of meatball X production is still not optimal. This study aims to make simulation modeling to maximize production and distribution in meatball $X$ production. The results of the research of the meatball manufacturing process go through 4 stages namely milling, emulsification, printing, and packaging. With a total production of 1200 pieces per day and produces a maximum income of IDR 1,800,000 with a net profit of IDR 1,025,000. To determine the shortest route and distribution path using the Dijkstra algorithm. From the Dijkstra calculation results the shortest route and path as far as $14.1 \mathrm{Km}$ with this route $X$ meatball production can shorten the distribution time and reduce costs for fuel.

\section{Keywords: Production, Distribution, Modelling, Simulation, Dijkstra}

\section{PENDAHULUAN}

Persaingan yang ketat pada zaman sekarang menuntut produsen untuk meningkatkan efektivitas serta efisiensi sumber daya manusia dan sumber daya bahan produk. Disisi lain produsen perlu memperhatikan aspek manajemennya karena dapat mengatur seluruh aktivitas dan kegiatan produksi secara efektif dan efisien. Sedangkan untuk menghasilkan output yang maksimal, produsen harus melihat kualitas bahan dan mempertimbangkan banyaknya penggunaan karena hal ini akan berpengaruh pada harga jual dan keuntungan yang didapatkan. Selain itu, untuk mendapatkan keuntungan yang maksimal, produsen juga harus memperhatikan strategi-strategi pemasaran.

Produksi bakso merupakan salah satu produksi industri kecil yang bergerak di bidang kuliner. Produksi ini merupakan makanan yang sangat populer dikalangan masyarakat Indonesia. Produksi bakso ini telah ada sejak lama dan berkembang di daerah desa maupun kota di seluruh penjuru Indonesia. Salah satunya produksi bakso X yang berada di Bungurasih, Sidoarjo, Jawa Timur.
Produksi ini sudah berdiri sejak tahun 2016 dan sudah memiliki banyak cabang yang tersebar di Sidoarjo dan Surabaya. Walaupun begitu, produksi bakso X masih belum memaksimalkan dari segi produksi dan distribusi. Strategi yang digunakan untuk saat ini hanya strategi pemasaran. Apabila ditelaah lebih dalam produksi bakso $\mathrm{X}$ dapat memaksimalkan keuntungan dari sisi produksi, biaya pembuatan, harga jual, saluran distribusi, dan lain-lain.

Penelitian Wibowo membahas tentang kinerja sistem produksi dengan melihat work in process pada masing-masing stasiun kerja (Wibowo, 2010). Disisi lain hasil penelitian yang dilakukan Retyana dengan penerapan algoritma Dijkstra dalam mencari lintasan terpendek pada pengiriman barang PT Kharisma Suma Jaya Sakti dapat diketahui yaitu 25,7 Km (Ekasari, 2017).

Merujuk pada riset sebelumnya dan permasalahan proses produksi pada bakso X masih belum maksimal, penelitian ini bertujuan agar produksi pada bakso $\mathrm{X}$ dapat maksimal dan memaksimalkan waktu distribusi bakso $\mathrm{X}$ dengan mencari rute terpendek. Untuk mencapai hal tersebut, maka permasalahan ini akan disimulasikan. 
Proses produksi dan distribusi pada bakso X akan dimodelkan dan disimulasikan.

\subsection{Produksi}

Produksi adalah menciptakan, menghasilkan, dan membuat sebuah produk. Produksi juga diartikan sebagai atau penggunaan atau pemanfaatan sumber daya yang mengubah suatu bahan mentah menjadi barang jadi (Herawati \& Mulyani, 2016).

Produksi adalah kegiatan untuk menciptakan faedah, waktu, bentuk, dan tempat yang didasarkan atas faktor-faktor produksi yang bermanfaat untuk pemenuhan konsumen (Setiawati, 2014).

Produksi adalah kegiatan untuk menciptakan, menghasilkan, dan membuat suatu barang. Kegiatan produksi tidak akan dapat dilakukan kalua tidak ada bahan yang akan diproses untuk menjadi suatu barang. Pengertian produksi lainnya yaitu hasil akhir dari sebuah proses atau aktivitas ekonomi dengan memanfaatkan masukan (TROTMAN-DICKENSON, 1969).

\subsection{Distribusi}

Distribusi merupakan salah satu dari aspek pemasaran. Distribusi diartikan sebagai kegiatan pemasaran untuk memperlancar dan mempermudah penyampaian barang atau jasa dari produsen kepada konsumen (Nugraha, 2016).

Dari berbagai pendapat diatas dapat ditarik kesimpulan bahwa distribusi adalah kegiatan menyalurkan dan mengirimkan barang atau jasa dari produsen ke konsumen akhir.

\subsection{Pemodelan}

Model adalah representasi dari suatu objek, benda, dan ide yang disederhanakan dari sebuah kondisi atau fenomena alam. Model berisi informasi-informasi tentang sebuah fenomena yang dibuat dengan tujuan untuk mempelajari fenomena yang terjadi (Iii \& Penelitian, 2014).

\subsection{Simulasi}

Simulasi adalah suatu model sistem dimana komponennya dipresentasikan oleh proses-proses aritmatika dan logika yang dijalankan komputer untuk memperkirakan sifat-sifat dinamis sistem tersebut. Pengertian lain dari simulasi adalah sistem yang digunakan untuk memecahkan atau menguraikan suatu masalah atau persoalanpersoalan dalam kehidupan nyata yang penuh dengan ketidak pastian dan lebih ditekankan pada pemakaian perangkat lunak komputer sebagai cara untuk mendapatkan solusinya (Munawar et al., 2013).

\subsection{Algoritma Dijkstra}

Algoritma Dijkstra diterapkan untuk mencari rute atau lintasan terpendek pada graph terarah. Namun, algoritma ini juga bisa diterapkan pada graph tidak berarah. Algoritma Dijkstra adalah salah satu algoritma efektif yang digunakan untuk menentukan atau mencari lintasan terpendek dari lokasi satu ke lokasi yang lainnya. Prinsip algoritma Dijkstra adalah mencari node lokasi dengan pencarian dua rute atau lintasan yang paling pendek (Yusuf, Az-zahra, \& Apriyanti, 2017).

Edsger W Dijkstra menemukan Algoritma Dijkstra pada tahun 1959 yang merupakan bentuk algoritma popular dalam memecahkan sebuah masalah yang terkait dengan optimasi dan bersifat sederhana. Algoritma Dijkstra menyelesaikan masalah yang berkaitan dengan mencari lintasan terpendek dari vertex a ke vertex $\mathrm{z}$ dalam graph berbobot. Bobot tersebut tidak boleh bilangan bernilai negatif dan harus bilangan bernilai positif.

\section{METODE PENELITIAN}

Penelitian ini merupakan jenis penelitian deskriptif kualitatif. Penulis menentukan tempat dan waktu penelitian dilaksanakan, dalam hal ini mempermudah peneliti dalam mengambil data sebagai referensi penelitian. Lokasi penelitian yaitu pada Bakso X yang terletak di Bungurasih, Sidoarjo, Jawa Timur. Penelitian ini dilakukan selama 1 bulan mulai bulan November sampai Desember 2019.

Dalam perancangan simulasi komputer menggunakan anylogic maka diperlukan perumusan ruang lingkup dan batasan studinya adalah sebagai berikut:

1. Sistem yang diamati yaitu sistem produksi bakso $\mathrm{X}$ mulai dari pengolahan pertama sampai akhir dan distribusi dari produsen sampai ke cabang.

2. Proses yang diamati yaitu proses produksi bakso $\mathrm{X}$.

3. Simulasi dilakukan selama 1 bulan.

Dalam penelitian ini dibagi menjadi beberapa tahapan seperti pada Gambar 1 .

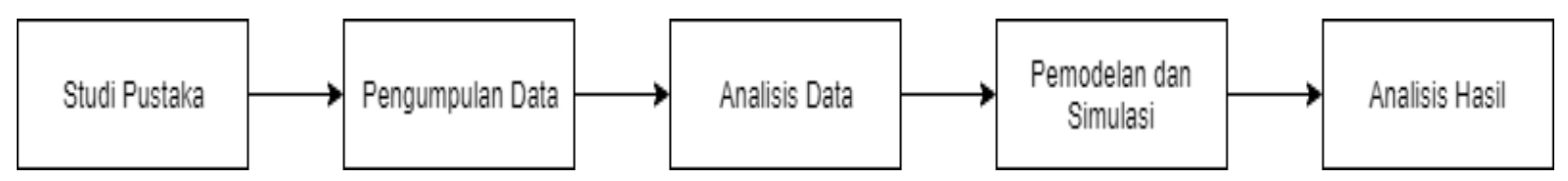

Gambar 1. Flowchart penelitian 
Pada Gambar 1 penelitian dimulai dari studi pustaka untuk menghimpun informasi yang berkaitan dengan penelitian ini. Tahapan selanjutnya adalah pengumpulan data. Dalam pengumpulan data peneliti menggunakan 3 metode yaitu :

\section{Study Literature}

Digunakan untuk menyusun dasar teori yang digunakan dalam penelitian ini. Sumber data yang digunakan untuk Study Literature dalam penelitian ini yaitu jurnal, tesis, buku, internet dan dokumen yang terkait.

2. Interview

Pengumpulan data yang digunakan adalah dengan melakukan tanya jawab atau wawancara. Dalam penelitian ini wawancara dilakukan secara langsung terhadap pemilik bakso X.

3. Pengamatan (Observasi)

Teknik pengumpulan data dimana peneliti melakukan pengamatan secara langsung terhadap objek yang akan diteliti. Dalam penelitian ini pengamatan dilakukan dengan mendatangi produksi bakso $\mathrm{X}$ untuk melihat proses kerja produksi dan distribusi bakso $\mathrm{X}$ yang berada di Bungurasih, Sidoarjo, Jawa Timur.

Setelah mendapatkan data yang dibutuhkan kemudian data tersebut dianalisis. Setelah data dianalisis kemudian membuat pemodelan dan simulasi. Tahapan terakhir yaitu analisis hasil dari pemodelan dan simulasi yang telah dibuat.

\section{HASIL DAN PEMBAHASAN}

\subsection{Pemodelan dan Simulasi Produksi}

Pemodelan dan simulasi produksi dilakukan untuk memodelkan dan menggambarkan aktivitas produksi pada bakso $\mathrm{X}$ yang disesuaikan dengan data yang telah diperoleh. Berikut pada Gambar 2 flowchart produksi bakso X.

Beberapa proses yang ada dalam proses produksi bakso X diantaranya :

1. Menyiapkan bahan-bahan yang akan digunakan.

2. Penggilingan

Penggilingan adalah proses penghancuran daging menjadi bentuk yang lebih kecil.

3. Emulsifikasi

Penambahan zat air kemudian diaduk menjadi adonan.

4. Penyetakan

Proses pembentukan adonan menjadi bulat.

5. Pengemasan

Proses pengemasan pentol yang sudah jadi.

Data produksi dalam implementasi pada anylogic:

\section{Source}

Berisi poin awal dalam sebuah model. Dalam studi kasus produksi berisi bahan yang akan digunakan.

2. Service

Dalam proses produksi bakso $\mathrm{X}$ terdapat 4 service. Yaitu : penggilingan, emulsifikasi, penyetakan, dan pengemasan.

3. Sink

Poin akhir pada model. Menandakan berakhirnya sebuah proses.

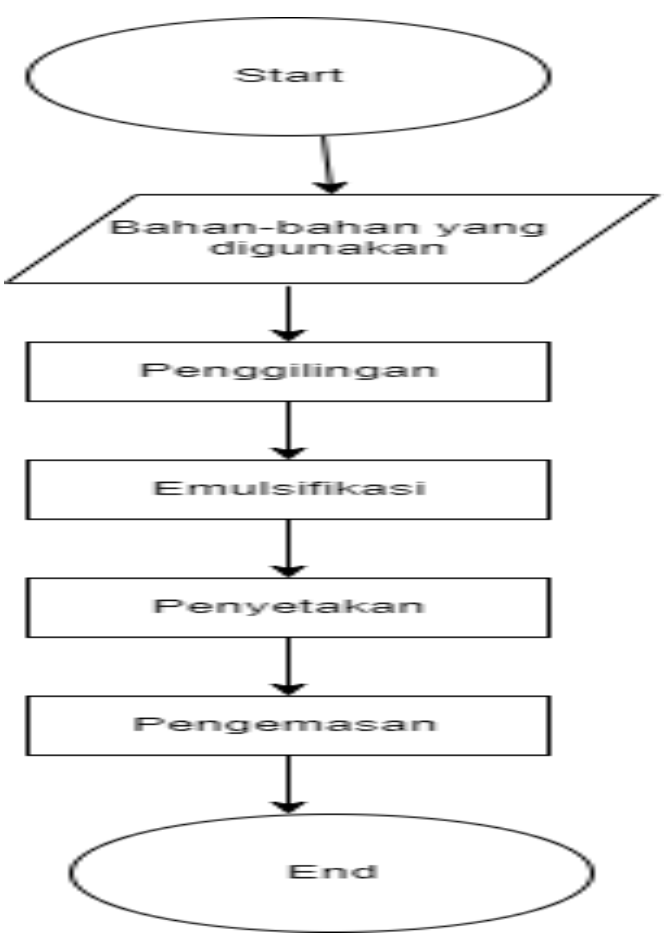

Gambar 2. Flowchart produksi bakso X 

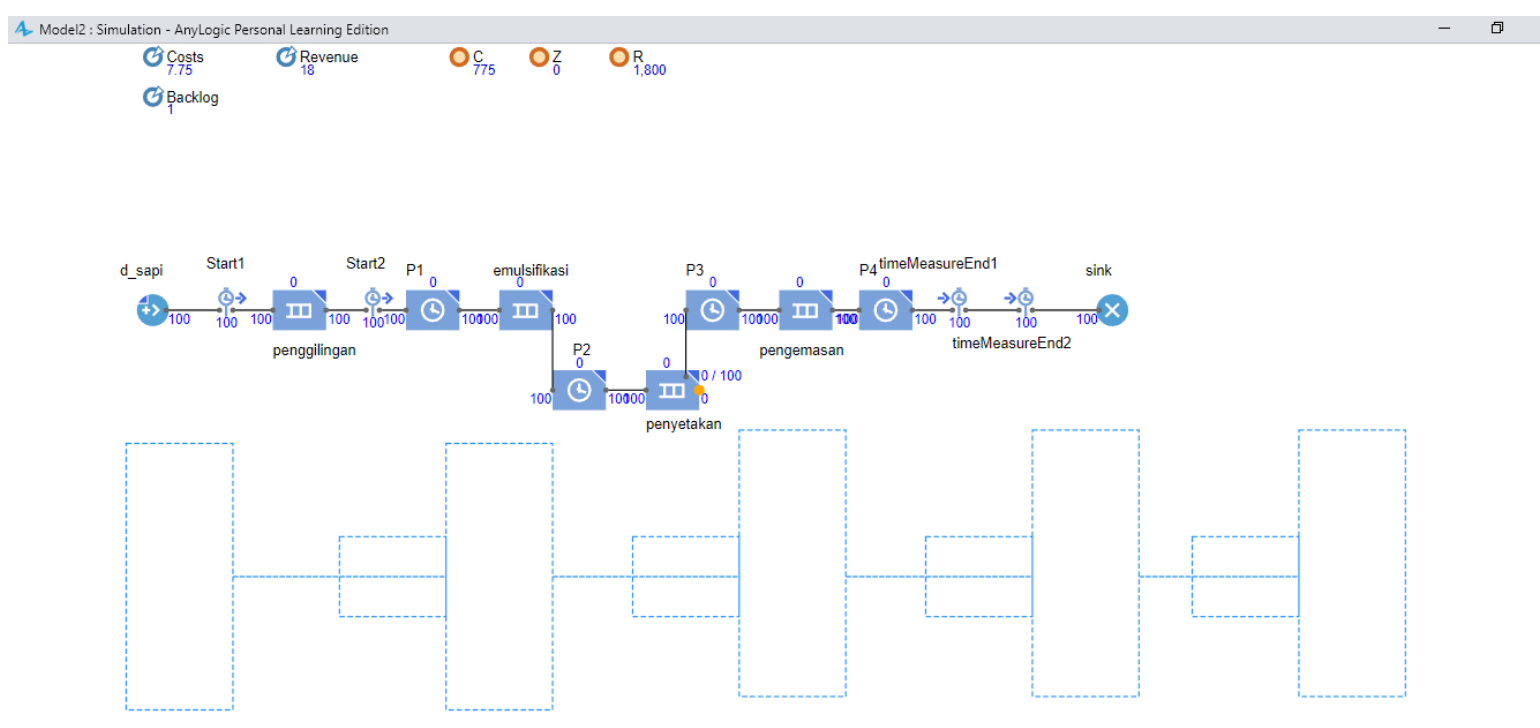

Gambar 3. Model produksi anylogic

Pada Gambar 3 merupakan model produksi pada bakso X. Dimulai dari source yang berisikan bahan-bahan yang akan digunakan dalam membuat bakso. Timemeasurestart adalah waktu dimulainya pembuatan. Penggilingan proses dimana daging sapi dan ayam dihaluskan. Daging yang sudah halus tersebut kemudian dicampurkan dengan bahanbahan yang lainnya untuk kemudian diemulsifikasi. Setelah itu, dicetak menjadi pentol. Setelah dicetak kemudian dikemas dan di distribusikan.

Dalam percobaan untuk menguji hasil maksimal, dengan manufaktur bakso dengan bahan
$10 \mathrm{~kg} /$ hari menghasilkan 120 buah pentol/kg bahan baku. Jadi, dalam sehari dapat memproduksi bakso sebanyak 1200 buah dengan harga Rp. 1.500 /satuan.

Proses pembuatan dijalankan dengan melalui 4 proses yaitu penggilingan, emulsifikasi, penyetakan, dan pengemasan. Efisiensi proses bisa dilihat pada Gambar 4 bagian utilization, yang setiap prosesnya memiliki tingkat pemanfaatan sebesar 23$26 \%$.
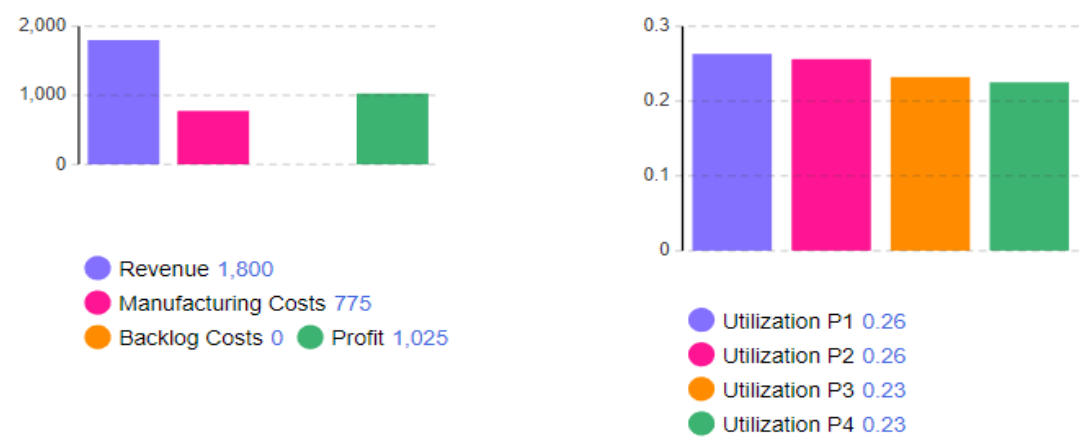

Gambar 4. Utilization

Hasil dari manufacturing bisa dilihat pada Gambar 4, untuk biaya bahan-bahan sebesar Rp. $77.500 / \mathrm{kg}$ bisa menghasilkan pendapatan total sebanya Rp. 180.000 dan keuntungan yang didapat setiap produksi sebesar Rp. 1.025.000 atau sebesar 12\%

\subsection{Distribusi}

Berdasarkan pengambilan data yang diperoleh dari produksi bakso $\mathrm{X}$ peneliti akan menyajikan dalam bentuk tabel. Tabel tersebut 
berisikan, alamat cabang bakso $\mathrm{X}$ dan nama titik pada gambar, untuk a1 merupakan tempat produksi bakso $\mathrm{X}$ dan merupakan titika awal pengiriman barang berikut adalah data hasil penelitian :

Tabel 1. Titik distribusi bakso $X$

\begin{tabular}{|l|c|}
\hline \multicolumn{1}{|c|}{ Alamat } & $\begin{array}{c}\text { Nama Titik } \\
\text { Pada Gambar }\end{array}$ \\
\hline $\begin{array}{l}\text { Jl. Tol Waru - Juanda Jl. } \\
\text { Berbek III No.16 }\end{array}$ & $\mathrm{a} 2$ \\
\hline Jl. Raya Jemursari No. 23 & $\mathrm{a} 3$ \\
\hline $\begin{array}{l}\text { Jl. Margorejo masjid } \\
\text { No.15d }\end{array}$ & $\mathrm{a} 4$ \\
\hline
\end{tabular}

Berdasarkan tabel diatas titik distribusi Bakso $\mathrm{X}$ dapat digambarkan dalam peta dibawah ini :

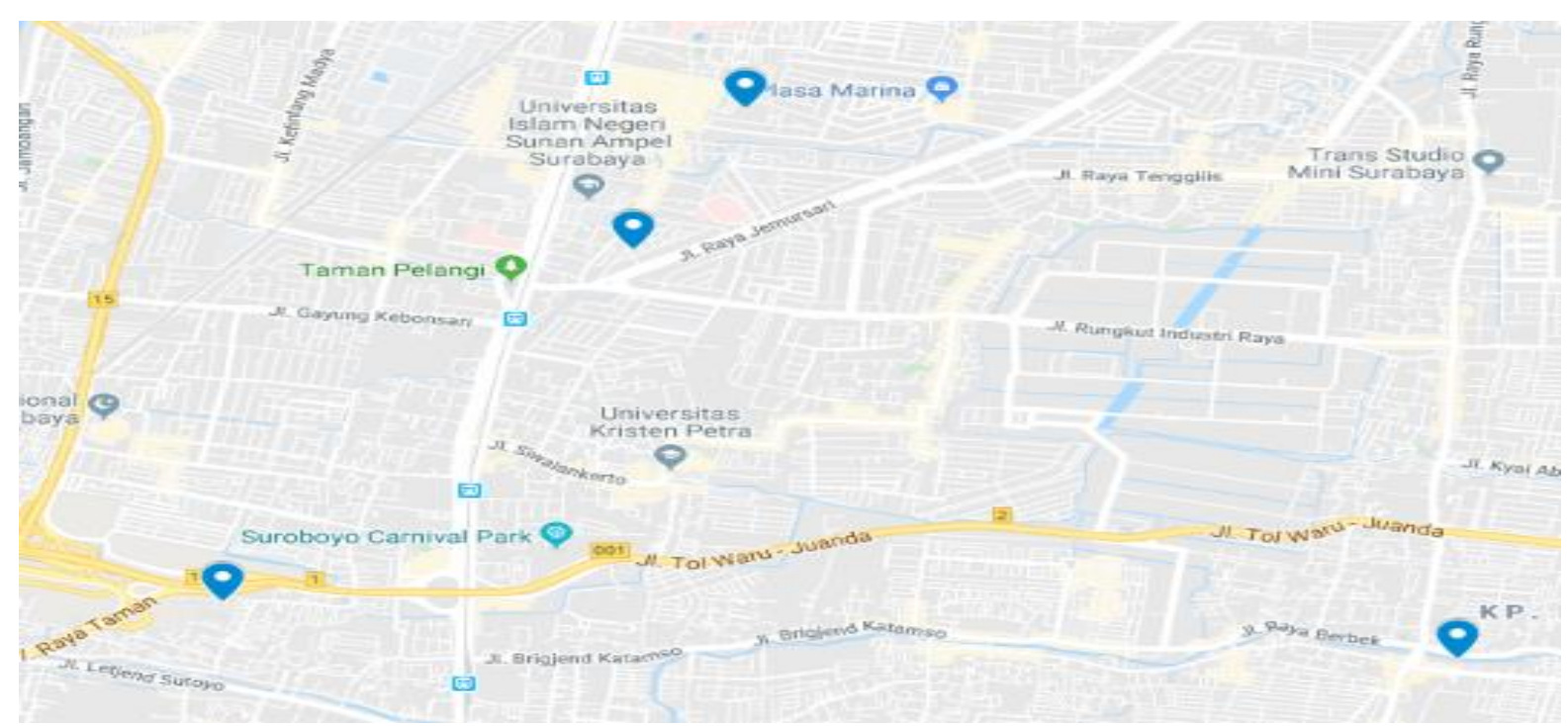

Gambar 4. Peta distribusi bakso X

Setelah mendapatkan data dari bakso X, yaitu titik distribusi, selanjutnya melakukan perhitungan jarak antar titik terhubung dan diperoleh hasil seperti tabel berikut :

Tabel 2. Jarak antar titik

\begin{tabular}{|c|c|}
\hline Titik Terhubung & Jarak $(\mathbf{K m})$ \\
\hline $\mathrm{a} 1-\mathrm{a} 2$ & 7,2 \\
\hline $\mathrm{a} 1-\mathrm{a} 3$ & 5,1 \\
\hline $\mathrm{a} 1-\mathrm{a} 4$ & 5,2 \\
\hline $\mathrm{a} 3-\mathrm{a} 4$ & 2,5 \\
\hline $\mathrm{a} 3-\mathrm{a} 2$ & 6,4 \\
\hline $\mathrm{a} 4-\mathrm{a} 2$ & 8,6 \\
\hline
\end{tabular}

Setelah didapatkan hasil jarak antar titik masing-masing titik akan dihubungkan dengan sebuah sisi, sisi tersebut melambangkan panjang jarak pada graph, seperti pada Gambar 4.

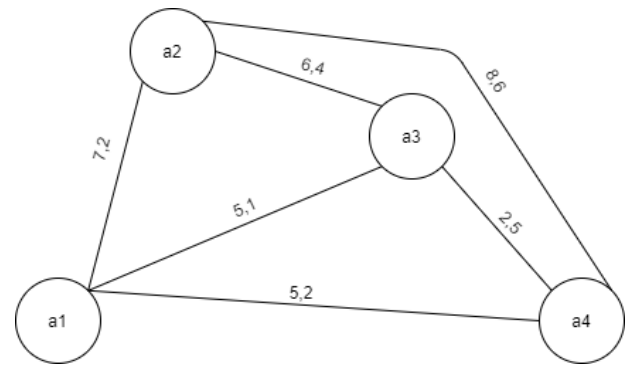

Gambar 5. Graph bakso X

Setelah mendapatkan data, selanjutnya menentukan perhitungan untuk rute terpendek pada distribusi bakso $\mathrm{X}$.

$$
\begin{aligned}
\text { a. } & \text { Rute } 1 \\
& =a 1+a 2+a 3+a 4 \\
& =0+7,2+6,4+2,5 \\
& =16,1 \\
\text { b. } & \text { Rute } 2 \\
& =a 1+a 3+a 2+a 4 \\
& =0+5,1+6,4+8,6 \\
& =20,1 \\
\text { c. } & \text { Rute } 3 \\
& =a 1+a 4+a 3+a 2 \\
& =0+5,2+2,5+6,4 \\
& =14,1 \\
\text { d. } & \text { Rute } 4 \\
& =a 1+a 3+a 4+a 2
\end{aligned}
$$



didapatkan model seperti pada Gambar 6 .

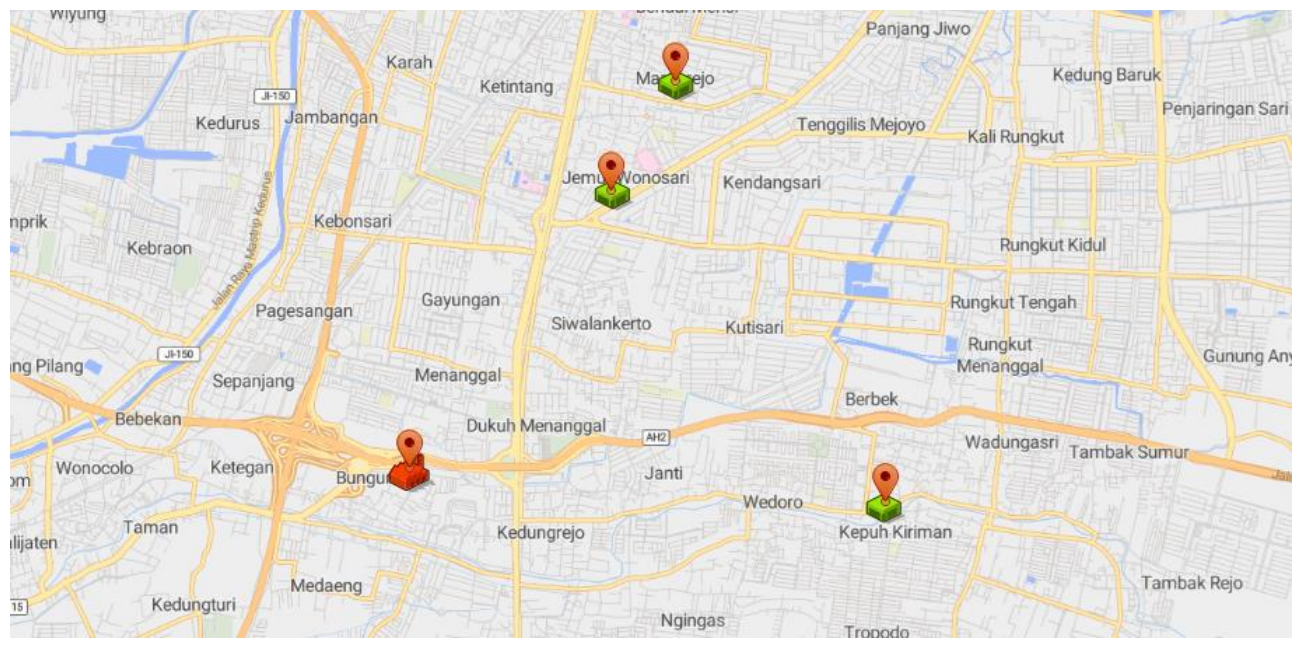

Gambar 6. Model peta distribusi.

Gambar 6 merupakan model peta distribusi dimana bangunan yang berwarna merah merupakan produsen atau tempat produksi, bangunan yang berwarna hijau merupakan cabang dari bakso X.

\section{KESIMPULAN DAN SARAN}

Dari hasil penelitian dan pembahasan pada bab 3 maka dapat ditarik kesimpulan sebagai berikut. Proses manufacturing bakso melewati 4 tahapan yaitu penggilingan, emulsifikasi, penyetakan, dan pengemasan. Dengan jumlah produksi perhari 1200 buah dan menghasilkan pendapatan maksimal sebesar Rp 1.800.000 dengan laba bersih sebesar Rp. 1.025.000. Hal tersebut mampu meningkatkan keuntungan sebesar Rp 200.000 yang semula pendapatan maksimal yang didapatkan adalah Rp. 1.600.000. Penerapan algoritma Dijkstra dalam mencari rute atau lintasan terpendek distribusi bakso X berdasarkan data yang diperoleh. Rute atau lintasan terpendek distribusi bakso X yaitu a1,a4,a3,a2 sejauh 14,1 Km.

\section{DAFTAR PUSTAKA}

Ekasari, R. F. (2017). Program studi pendidikan matematika fakultas keguruan dan ilmu pendidikan (fkip) universitas nusantara pgri kediri 2017. 1-12.

Herawati, H., \& Mulyani, D. (2016). PENGARUH KUALITAS BAHAN BAKU DAN PROSES PRODUKSI TERHADAP KUALITAS PRODUK PADA UD. TAHU ROSYDI PUSPAN MARON PROBOLINGGO Herlin. Prosiding Seminar Nasional, ISBN 978-6, 463-482.

Iii, B. A. B., \& Penelitian, M. (2014). Sarliaji Cayaray, 2014 Model layanan perpustakaan sekolah luar biasa Universitas Pendidikan
Indonesia | repository.upi.edu | perpustakaan.upi.edu.

Munawar, R., Cahyana, R., Nurwandi, L., Informatika, J. T., Tinggi, S., Garut, T., \& Carlo, S. M. (2013). Model simulasi perawatan sepeda motor. 10(01), 416-425.

Nugraha, S. S. (2016). Analisis Rantai Distribusi Komoditas Padi Dan Beras Di Kecamatan Jatiwangi Kabupaten Majalengka. 11-52. Retrieved from http://repository.unpas.ac.id/13281/

Setiawati, F. (2014). Analisis Pengendalian Proses Produksi Untuk Meningkatkan Kualitas Produk Pada Perusahaan PT. Batik Dan Liris Sukoharjo. Universitas Muhammadiyah Surakarta, 1.

TROTMAN-DICKENSON, D. I. (1969). Factors of Production: Capital. Economic Workbook and Data, 88-91. https://doi.org/10.1016/b978-0-08-0129587.50014-6

Wibowo, A. (2010). Model SimulasiI Kinerja Produksi Teh untukMinimasi Work-InProces. Jurnal Optimasi Sistem Industri, 9(1), 7. https://doi.org/10.25077/josi.v9.n1.p712.2010

Yusuf, M. S., Az-zahra, H. M., \& Apriyanti, D. H. (2017). Implementasi Algoritma Dijkstra Dalam Menemukan Jarak Terdekat Dari Implementasi Algoritma Dijkstra Dalam Menemukan Jarak Terdekat Dari Lokasi Pengguna Ke Tanaman Yang Di Tuju Berbasis Android ( Studi Kasus di Kebun Raya Purwodadi ). Jurnal Pengembangan Teknologi Informasi Dan Ilmu Komputer, 1(August), 1779-1781. 